\title{
Amino Acid Requirements of Gilthead Bream (Sparus aurata) Juveniles
}

\author{
M. M. Gaber ${ }^{1}$, M. El-S. Salem², M. A. Zaki' ${ }^{3}$, A. M. Nour ${ }^{3}$ \\ ${ }^{1}$ National Institute of Oceanography and Fisheries, Cairo, Egypt \\ ${ }^{2}$ National Institute of Oceanography and Fisheries, Alexandria, Egypt \\ ${ }^{3}$ Departments of Animal and Fish Production, Faculty of Agriculture, Alexandria University, El Shatby, Egypt \\ Email: "gabermagdy@yahoo.com
}

Received 27 June 2016; accepted 27 August 2016; published 30 August 2016

\begin{abstract}
In one trial 360 gilthead bream fingerlings received two different feed mixtures containing two different levels of protein (diet A 400 and B $360 \mathrm{~g} \cdot \mathrm{kg}^{-1}$ ). The average initial live weight was about $2.2 \pm 0.1 \mathrm{~g} \mathrm{fish}^{-1}$ in each replicate of all treatments. Sixty fish per tank were stocked randomly in 6 fiberglass tanks $\left(1 \mathrm{~m}^{3}\right.$ each). Fish were fed with experimental diets at rate $8 \%$ of the body weight daily. The Amino Acids (AA) content was analyzed in the diets, whole fish and muscle at the end of the growth period ( 60 days). The results indicated that at the end of experiment gilthead bream fingerlings had reached an average live weight 18.5 and $16.2 \mathrm{~g} \mathrm{fish}^{-1}$ for fish fed diet $A$ and $B$ respectively. Also the increase of protein levels in the feed to $40 \%$ caused a significant increase in the content of Indispensable Amino Acid (IAA) and dispensable amino acid (as \%v of whole fish and muscle of wet weight). Two methods were subsequently used to estimate the quantitative IAA requirements of gilthead bream fry based on the hypothesis that (a) the dietary requirement pattern of IAA reflected the tissue pattern and (b) the rate of daily deposition in the fish could be equated with the dietary requirement as percentage of $100 \mathrm{~g}^{-1}$ diet. The quantitative IAA requirement (\%) of gilthead bream (Sparus aurata) diets was as follow: Lysine 2.27, Methionine 1.09, Therionine 0.61, Leucine 2.4, Isoleucine 0.47, Histidine1.6, Arginine 1.39, Phenylalanine 1.43, Valine 1.22 and Tryptophane 0.42 .
\end{abstract}

\section{Keywords}

Amino Acid Requirements, Gilthead Bream, Whole Body, Tissues

\section{Introduction}

Formulation of diets with an optimum Essential Amino Acid (EAA) profile and adequate protein content is a prerequisite for improving Amino Acid (AA) utilization for growth, and thereby reducing Nitrogen (N) excretion. This is particularly important in carnivorous fish, like gilthead sea bream, which uses protein preferentially to lipids or carbohydrates as an energy source [1].

The values of amino acids content, when expressed as a proportion of the diet, indicate large variations in the requirements of different species. Dietary amino acids are needed for growth and maintenance and the former is ${ }^{*}$ Corresponding author.

How to cite this paper: Gaber, M.M., Salem, M.El-S., Zaki, M.A. and Nour, A.M. (2016) Amino Acid Requirements of Gilthead Bream (Sparus aurata) Juveniles. World Journal of Engineering and Technology, 4, 18-24. 
quantitively much more important in young rapidly growing fish.

The occurrence of an imbalance of amino acids in fish nutrition is nevertheless possible. Indeed if proteinsparing feed is provided to fish, the amino acids supply in the feed must be adjusted to meet fish needs. Many investigators had varying degree of success in using practical test diets to determine amino acids requirements [2]-[4]. Even when fed nutrient-energy dense diets, based on high quality protein sources, under culture conditions which enable optimal growth performance to be achieved, gross protein retention of sea bass and bream usually ranges between $25 \%$ - 35\% making them poor protein converters in comparison to salmonids [5]. The results of various experiments have shown that the smallest elimination of endogenous $\mathrm{N}$ occurs when the used feed has an amino acid makeup most close to the body protein [6].

The IAA pattern of the whole body of gilt head bream has been considered to be representative of the IAA requirement profile of that species [7] [8]. The present work was undertaken to analyze the whole body amino acid composition of gilthead bream currently cultivated in Egypt and to draw an estimation of their IAA requirements, based on the relative proportions of whole body IAA.

\section{Material and Methods}

Food mixture consists of fish meal, soybean meal, wheat bran, and fish oil according to Table 1. Two different food mixture were made by combined two different levels of protein diet $\mathrm{A}\left(400 \mathrm{~g} \cdot \mathrm{kg}^{-1}\right)$ and diet $\mathrm{B}\left(360 \mathrm{~g} \cdot \mathrm{kg}^{-1}\right)$.

The experiment was conducted in six fiberglass tanks $\left(1 \mathrm{~m}^{3}\right.$ each) of saline water. In each tank about two third of saline water volume was daily replaced by aerated fresh saline solution after cleaning and removing the accumulated excreta. All tanks were supplied with compressed air for oxygen requirements. Fish were exposed to the natural light conditions. Fish in each aquarium were fed twice daily (six days a week) at a rate of $8 \%$ of body weight during the experimental period.

Table 1. Composition and proximate analysis of the experimental diets.

\begin{tabular}{|c|c|c|}
\hline \multirow{2}{*}{ Ingredients (\%) } & \multicolumn{2}{|c|}{ Diets } \\
\hline & A & B \\
\hline Fish meal (C.P.60\%) & 30.0 & 30.0 \\
\hline Soybean meal (C.P.44\%) & 50.0 & 40.0 \\
\hline Wheat bran & 6.0 & 16.0 \\
\hline Fish oil & 4.5 & 2.5 \\
\hline Sunflower oil & 3.0 & 3.0 \\
\hline Cellulose & 0.5 & 2.3 \\
\hline Vit. \& Min premix ${ }^{1}$ & 3.0 & 3.0 \\
\hline Calcium diphosphate & 2.0 & 2.0 \\
\hline Molasses $^{2}$ & 0.8 & 1.0 \\
\hline Furazolidone & 0.01 & 0.01 \\
\hline Vitamin C & 0.2 & 0.2 \\
\hline \multicolumn{3}{|l|}{ Proximate analyses $(\%)^{3}$} \\
\hline Moisture & 8.2 & 9.2 \\
\hline Crude protein & 40.13 & 36.25 \\
\hline Crude fat & 12.53 & 10.07 \\
\hline Ash & 6.1 & 6.96 \\
\hline Crude fiber & 4.0 & 6.67 \\
\hline $\mathrm{NFE}^{4}$ & 28.24 & 30.86 \\
\hline Gross energy Kcal & 4332 & 4235 \\
\hline
\end{tabular}

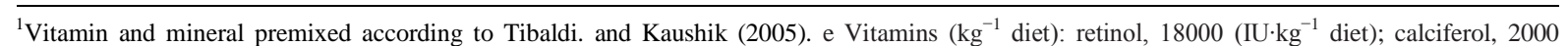
(IU $\mathrm{kg}^{-1}$ diet); alpha tocopherol, 35; menadion sodium bis., 10; thiamin, 15; riboflavin, 25; Ca pantothenate, 50; nicotinic acid, 200; pyridoxine, 5; folic acid, 10; cyanocobalamin, 0.02; biotin, 1.5; ascorbyl monophosphate, 50; and inositol, 400. fMinerals (mg. $\mathrm{kg}^{-1} \mathrm{diet}$ ): cobalt sulphate, 1.91; copper sulphate, 19.6; iron sulphate, 200; sodium fluoride, 2.21; potassium iodide, 0.78; magnesium oxide, 830; manganese oxide, 26; sodium selenite, 0.66; zinc oxide, 37.5 ; potassium chloride, $1.15\left(\mathrm{~g} \cdot \mathrm{kg}^{-1} \mathrm{diet}\right)$; sodium chloride, $0.40\left(\mathrm{~g} \cdot \mathrm{kg}^{-1}\right.$ diet $)$; ${ }^{2}$ Molasses was used as a binder and attractant according to El-Saidy and Gaber (1998); ${ }^{3}$ Values represent the mean of three sample replicates. ${ }^{4} \mathrm{NFE}=100-(\%$ protein $+\%$ fat $+\%$ fiber $+\%$ ash $)$. 
Water temperature and dissolved oxygen were measured every other day using an YSI Model 58 oxygen meter (Yellow Springs Instruments, Yellow Springs, OH). Ammonia and nitrite were measured at wkly intervals. Alkalinity was monitored twice weekly using the titration methods of [9] $\mathrm{pH}$ was monitored twice weekly using an electronic $\mathrm{pH}$ meter ( $\mathrm{pH}$ pen Fisher Scientific, Cincinnati, $\mathrm{OH}$ ). During the feeding trial, the water quality parameter averaged $( \pm \mathrm{SD})$ : water temperature $27.8^{\circ} \mathrm{C} \pm 0.8^{\circ} \mathrm{C}$ dissolved oxygen $4.8 \pm 0.4 \mathrm{mg} \cdot l^{-1} ; \mathrm{pH} 7.4 \pm 0.6$; ammonia $\pm 0.04 \mathrm{mg} \cdot 1^{-1}$; nitrite $0.1 \pm 0.05 \mathrm{mg} \cdot \mathrm{l}^{-1}$; nitrate $1.5 \pm 0.2 \mathrm{mg} \cdot \mathrm{l}^{-1}$; alkalinity $181 \pm 46 \mathrm{mg} \cdot \mathrm{l}^{-1}$.

A set of 360 gilthead bream (Sparus aurata) fingerling obtained from Fish Hatchery, National Institute of Oceanography \& Fisheries Alexandria Branch, Egypt were used in the present study. Fish were placed randomly in 6 fiberglass tanks ( $1 \mathrm{~m}^{3}$ each); three replicates per treatment were used in this study. Each tank was stocked with sixty fingerlings of gilthead bream with an average initial body weight of $2.21 \pm 0.01 \mathrm{~g}$ fish. To minimize stress of handling, fish from each aquarium were weighed every 2 weeks and at the end of the feeding trial (60 days). Thereafter, six fish per replicate for each treatment under study were killed and kept in the freezer. For preparation of samples the frozen sea bass were slightly cut into parts minced and then homogenized. The dry matter $(\mathrm{DM})$ and crude protein $(\mathrm{N} \times 6.25)$ were determined according to [10].

According to [11], three hydrolyses were carried out for each sample, the amino acid composition in each hydrolysat was determined with the help of the automatic amino acid analyzer AAA-339 (M-USSR). The amino acid determination of the feed ration was done in an analogue way to the method for the animal carcasses. Tryptophane was determined according to the method of [12].

The IAA value were evaluated with the help of the SAS program package as one way classification analysis of variance with application of the student Newman keuls test. The IAA pattern of whole fish and muscle was then determined by expressing each of the ten EAA as a percentage of the sum of EAA. This pattern is required in the diet of gilthead bream was calculated by assuming the lysine requirement to be $2.0 \%$ of diet [13] and adjusting the levels of the other EAA accordingly.

[14] proposed a method for determination of the quantitative IAA requirements of fish based on determination the rate of deposition of each of ten IAA as g/100g fish/day. Samples of fish, fed $40 \%$ and $36 \%$ crude protein feed, were analyzed for IAA as described before and the daily rate of deposition calculated. According to feeding rate of $8 \%$ of the body weight/day of $40 \%$ and $36 \%$ protein feed with a protein digestibility of $90 \%$ were assumed.

\section{Results and Discussion}

The mean contents of indispensable and dispensable amino acid acids, given as \% of diets and \% wet carcass for each of the two treatments, are shown in Table 1 \& Table 2. The one way statistical evaluation shows that differing in protein supplies have a significant effect on the protein content and all amino value of gilthead bream. Because the relative amino acid content at protein level $400.0 \mathrm{~g} \cdot \mathrm{kg}^{-1}$ diet was higher than that of lower protein level $360 \mathrm{~g} \cdot \mathrm{kg}^{-1}$ diet.

The results (Table 1 \& Table 2) demonstrate, however, that changes in the amino acid content depend on the protein content in gilthead bream. The degree to which the amino acid pattern of gilthead bream protein was affected can be observed by the value of amino acids content per $100 \mathrm{~g}$ fish weight. Thus the content of indispensable and dispensable amino acid acids is clearly decreased by increasing the protein levels in the feed from 360 - $400 \mathrm{gkg}^{-1}$ diet. A variable dietary protein and energy supply significantly affects the protein content and protein retention of carp [15] [16].

Practical diets for marine fish are also developing through a large use of plant proteins where limiting supplies, excess or imbalances of dietary AA might be leading to depressed feed intake, growth retardation and nutritional pathologies. Changes in feed consumption may be regarded as the primary response to dietary AA disproportions in several animal models [17] and although no systematic work has been done so far in the fish species studied to date, there is evidence that voluntary feed intake in young gilthead bream may be affected to some extent by limiting or excessive levels of certain IAA in the diet. In contrast, the various protein and energy level had no influence on the amino acid pattern of gilthead bream protein. This result agrees well with our results of work in which the amino acids composition of the body protein could not be changed by varying the levels of chitosan. Deviations in the amino acids compositions of the body protein are only conceivable under extreme conditions, for example, when a shift in tissue ratio is accompanied by a varying amino acids pattern. Yet, in this work it has been shown that sea bass with different live weight (4.3 g to $200 \mathrm{~g}$ ) has the same amino acids pattern. 
Table 2. Content of essential and none essential amino acids in the experimental diets with varying levels of protein supply $\mathrm{g} \cdot \mathrm{kg}^{-1}$.

\begin{tabular}{ccc}
\hline & & Diets \\
Amino acids & $\mathrm{A}\left(400 \mathrm{~g} \cdot \mathrm{kg}^{-1}\right)$ & $\mathrm{B}\left(360 \mathrm{~g} \cdot \mathrm{kg}^{-1}\right)$ \\
\cline { 2 - 3 } Indispensable amino acids (\%) & & 5.09 \\
Lysine & 5.13 & 0.54 \\
Methionine & 1.56 & 0.95 \\
Therionine & 1.02 & 0.30 \\
Leucine & 1.17 & 0.46 \\
Isoleucine & 0.55 & 1.26 \\
Histidine & 1.1 & 1.33 \\
Arginine & 1.25 & 0.18 \\
Phenylalanine & 0.22 & 0.18 \\
Valine & 0.33 & 0.18 \\
Tryptophane & 0.33 & 2.4 \\
Alanine & & 3.95 \\
Aspartic acid & 3.29 & 0.90 \\
Cystine & 2.49 & 2.39 \\
Glycine & 0.66 & 5.89 \\
Glutamic acid & 2.38 & 5.39 \\
Proline & 6.41 & 2.52 \\
Serine & 5.93 & 0.60 \\
tyrosine & 2.34 & 1.09 \\
\hline
\end{tabular}

Similarly, it was demonstrated that, carp with different live weights has the same amino acids composition in the entire bodies [18].

The sparse available data which are concerned with the amino acid composition of protein in the carcasses or edible portions of different salmonids, sea bass and tilapia [19]-[21] do exhibit general agreement with the work presented here. In addition, a more recent study done with 12 different salt water fish species, also confirms the quite uniform amino acid pattern [22]. The studies of [19] [23] showed higher indispensable amino acids content in the edible portions of carp, trout and Nile tilapia as compared to the indispensable amino acids in the whole fish.

As mentioned earlier, [6] [20] [24] [25] provided clues to optimum amino acid requirements and composition of feed protein. But it should be discussed to what degree the amino acids composition of carcass protein can be used in metabolism and serve as building blocks for further body substances as methionine, and phenylalanine. In addition, maintenance metabolism and the rate of re-utilization of individual amino acid must be taken into account [26], the comparison of the amino acid pattern in the whole fish and muscle with that of the feed protein should at least make manifest any gross amino acids metabolism. In Table 2, Leucine was presented in feed protein in relatively high amount in comparison to lysine.

The amino acid pattern which corresponds to the recommendations based upon requirement and adjustments of these amino acids can be also regarded as oriented in the amino acid compositions of gilthead bream protein. Leucine is clearly defiant and is regarded as necessary in significantly lower amounts. In addition, Methionine and phenylalanine appear in somewhat lower relative amounts (Table 3). While, [27] reported that 50\% of Tyrosine can substitute for phenylalanine and $60 \%$ of Cystine can substitute for Methionine.

Similar conclusions can be drown from the work of [24], to what degree the amino acid composition of gilthead bream and fish feed protein is actually useful in determining a need-oriented amino acid supply in food.

Data in Table 4 shows that values of indispensable amino acids in whole fish and muscle and daily deposition of gilthead bream relation to lysine (lys. $=2.0$ ) is corresponding to the recommendations for minimum amino acids requirements [13] [14] [29]. The feed protein in question must be considered to be high grade based upon its composition and high digestibility of $87 \%$ - 94\% [30]. It is obvious that the amino acid composition of the feed protein corresponds well with the amino acid composition of gilthead bream protein [31]. [32] showed that 
Table 3. Indispensable amino acid and dispensable amino acid in whole and muscle of gilthead bream (Sparus aurata).

\begin{tabular}{|c|c|c|c|c|}
\hline \multirow{2}{*}{ Parameters } & \multicolumn{4}{|c|}{ Diets } \\
\hline & \multicolumn{2}{|c|}{ A } & \multicolumn{2}{|c|}{ B } \\
\hline & \multicolumn{2}{|c|}{$13.06 \pm 0.3$} & \multicolumn{2}{|c|}{$10.45 \pm 4.5$} \\
\hline $\begin{array}{l}\left.\text { Final fish weight ( } \mathrm{g} \mathrm{fish}^{-1}\right) \\
\text { protein level }\left(\mathrm{g} \cdot \mathrm{kg}^{-1} \mathrm{diet}\right)\end{array}$ & \multicolumn{2}{|c|}{400.0} & \multicolumn{2}{|c|}{360.0} \\
\hline Treatments (\%) & Whole fish & Muscle & Whole fish & Muscle \\
\hline \multirow{2}{*}{ Moisture content (\%) } & 18.5 & 19.64 & 16. 2 & 17.77 \\
\hline & 70.65 & 72.45 & 73.0 & 73.62 \\
\hline \multicolumn{5}{|c|}{ Indispensable amino acids (\%) } \\
\hline Lysine & 0.85 & 1.26 & 0.82 & 1.21 \\
\hline Methionine & 0.38 & 0.5 & 0.36 & 0.49 \\
\hline Therionine & 0.24 & 0.29 & 0.23 & 0.28 \\
\hline Leucine & 0.85 & 1.18 & 0.82 & 1.15 \\
\hline Isoleucine & 0.22 & 0.22 & 0.21 & 0.21 \\
\hline Histidine & 0.68 & 1.01 & 0.65 & 1.0 \\
\hline Arginine & 0.58 & 0.68 & 0.56 & 0.66 \\
\hline Phenylalanine & 0.62 & 0.7 & 0.5 & 0.6 \\
\hline Valine & 0.58 & 0.6 & 0.56 & 0.58 \\
\hline Tryptophane & 0.2 & 0.2 & 0.24 & 0.26 \\
\hline \multicolumn{5}{|c|}{ Dispensable amino acids (\%) } \\
\hline Alanine & 0.98 & 1.04 & 0.86 & 0.95 \\
\hline Aspartic acid & 1.9 & 2.01 & 1.66 & 1.84 \\
\hline Cystine & 0.81 & 0.86 & 0.71 & 0.79 \\
\hline Glycine & 0.65 & 0.69 & 0.57 & 0.63 \\
\hline Glutamic acid & 2.45 & 2.60 & 2.15 & 2.39 \\
\hline Proline & 0.98 & 1.04 & 0.86 & 0.95 \\
\hline Serine & 0.51 & 0.54 & 0.45 & 0.49 \\
\hline Tyrosine & 0.17 & 0.18 & 0.15 & 0.17 \\
\hline
\end{tabular}

Table 4. The quantitative EAA requirement (\%) of gilthead bream (Sparus auratus).

\begin{tabular}{ccccccc}
\hline \multirow{2}{*}{ Amino acid } & \multicolumn{2}{c}{ Basic of Calculation } & $\begin{array}{c}\text { Daily } \\
\text { deposition }\end{array}$ & $\begin{array}{c}\text { Determined } \\
\text { IAA for Sea } \\
\text { bass as \% diet }\end{array}$ & $\begin{array}{c}\text { Determined IAA } \\
\text { for as g 16 g·N }\end{array}$ & $\begin{array}{c}\text { Required }^{3} \\
\mathrm{~g}^{2} 16 \mathrm{~N}\end{array}$ \\
\cline { 2 - 3 } Lysine & 1.98 & 1.98 & 2.82 & 2.27 & 5.05 & 4.7 \\
Methionine & 2.02 & 2.03 & 1.56 & 1.09 & 2.42 & 2.2 \\
Therionine & 2.17 & 2.03 & 0.74 & 0.61 & 1.35 & 2.4 \\
Leucine & 1.65 & 1.66 & 3.24 & 2.4 & 5.32 & 4.1 \\
Isoleucine & 0.9 & 0.91 & 0.49 & 0.47 & 1.12 & 2.5 \\
Histidine & 1.21 & 1.22 & 1.59 & 1.6 & 3.54 & 1.3 \\
Arginine & 1.77 & 1.78 & 1.68 & 1.39 & 3.08 & 3.7 \\
Phenylalanine & 0.51 & 0.5 & 1.59 & 1.43 & 3.17 & 4.1 \\
Valine & 0.48 & 0.48 & 1.73 & 1.22 & 2.7 & 2.8 \\
Tryptophane & 0.37 & 0.38 & 0.32 & 0.42 & 0.94 & 0.5 \\
\hline
\end{tabular}

${ }^{1}$ Whole fish or muscle $=1.98 /$ determined lysine $\mathrm{x}$ amino acid $\%$ (according to [28]. ${ }^{2}$ IAA deposition = protein efficiency ratio $\mathrm{x}$ amino acid $\%$ according to [14]; ${ }^{3}$ According to [13]. 
for the chick a direct correlation existed between the tissue IAA pattern and dietary requirements pattern. [3] Showed that, this was also true for carp. Generally, the requirements based on the two tissues were close agreement with main exception low methionine requirement is predicted from muscle tissue analysis [33].

Table 4 shows the results of experiments, where the method of [14] equating the deposition rate of each of IAA with requirement was used. The results are in close agreement with those obtained in Table 3 . Neither the method of [32] nor [14] take into account the metabolic rate of IAA other that for protein synthesis is particularly no allowance is made for the maintenance requirement for the IAA. However, it is unlikely that maintenance will change the requirement pattern [32] and should only have slight influence on the absolute dietary requirements.

In conclusion the IAA requirements pattern of gilthead bream is not dissimilar to that or other fish species. Nevertheless the absolute dietary requirements are sufficiently different as to necessitate formulation of diets on a species specific basis. The quantitative IAA requirement (\%) of sea bass (Dicentrarchus labrax) diets is as follow: Lysine 2.27 Methionine 1.09 Therionine 0.61 Leucine 2.4 Isoleucine 0.47 Histidine1.6 Arginine 1.39 Phenylalanine 1.43 Valine 1.22 tryptophane 0.42 (g/100g diet).

\section{References}

[1] Peres, H. and Oliva-Teles, A. (1999) Influence of Temperature on Protein Utilization in Juvenile European Seabass (Dicentrarchus labrax). Aquaculture, 170, 337-348. http://dx.doi.org/10.1016/S0044-8486(98)00422-0

[2] Ogino, C. and Nanri, M. (1980) Relationship between the Nutritive Value of Dietary Protein for Rainbow Trout and the Essential Amino Acid Composition. Bulletin Japanese Science Society Fish, 146, 109-112. http://dx.doi.org/10.2331/suisan.46.109

[3] Cowey, C.B. and Tacon, A.G.J. (1981) Fish Nutrition Relevance to Invertebrates. Presented at 2nd Int. Cont. on Aquaculture Nutrition Biochemical Approaches to Shell Fish Nutrition, Univ. of Delaware, 27-29 October 1981.

[4] Wilson, R.P. and Poe, W.E. (1985). Apparent Digestible Protein and Energy Coefficients of Common Feed Ingredients for Channel Catfish. Progressive Fish-Culturist, 47, 154-158. http://dx.doi.org/10.1577/1548-8640(1985)47<154:ADPAEC>2.0.CO;2

[5] Tibaldi, E. and Kaushik, S.J. (2005) Amino Acid Requirements of Mediterranean Fishes Pecies. In: Montero, D., Basurco B., Nengas, I., Alexis, M. and Izquierdo, M., Eds., Mediterranean fish nutrition Zaragoza: CIHEAM Cahiers Options Méditerranéennes, n. 63

[6] Fuller, M.F., Ston, R.M., Baird, B.A. and Atkeinson, T. (1979) The Optimal Amino Acid Supplementation. British Journal of Nutrition, 41, 321-331. http://dx.doi.org/10.1079/BJN19790041

[7] Mambrini, M. and Kaushik, S.J. (1995) Indispensable Amino Acid Requirements of Fish: Correspondence between Quantitative Data and Amino Acid Profiles of Tissue Proteins. J. Appl. Ichthyol, 11, 240-247. http://dx.doi.org/10.1111/j.1439-0426.1995.tb00024.x

[8] Wilson, R.P. and Cowey, C.B. (1985) Amino Acid Composition of Whole Body Tissue of Rainbow Trout and Atlantic Salmon. Aquaculture, 48, 373-376. http://dx.doi.org/10.1016/0044-8486(85)90140-1

[9] Golterman, H.L., Clymo, R.S. and Ohnstad, M. A. M. (1978) Methods of Physical and Chemical Analysis of Fresh Waters. Blackwell Scientific Publications, Oxford, 214 p.

[10] AOAC (Association of Official Analytical Chemists) (2006) Official Methods of Analysis. 18th Edition, Washington DC, 1018.

[11] Mason, E.A., Lin, S.L. and Gatland, I.R. (1079) Mobility and Diffusion of Protons and Deuterons in Helium—A Runaway Effect. Journal of Physics B: Atomic and Molecular Physics.

[12] Blauth, O.J., Chareinski, M., Berlie, H. (1963) A new Rapid Method for Determining Tryptophan. Anal. Biochem, 6, 69. http://dx.doi.org/10.1016/0003-2697(63)90009-5

[13] Tibaldi, E. and Lanari, D. (1991) Optimal Dietary Lysine Levels for Growth and Protein Utilisation of Fingerling Sea Bass (Dicentrarchus labrax) Fed Semipurified Diets. Aquaculture, 95, 297-304. http://dx.doi.org/10.1016/0044-8486(91)90095-O

[14] Ogino, C. (1980) Requirements of Carp and Rainbow Trout for Essential Amino Acid. Bulletin Japanese Science Society Fish, 46, 171-174.

[15] Schwarz, F.J., Zeitler, M.H. and Kirchgessner, M. (1984) Ansatz and Vewertung von protein beikarpfen (Cyprinus carpio L) mit untersch-iedlicher protein und Energiev-sorgung. Arch. Tierernbaha, 34, 165-178. http://dx.doi.org/10.1080/17450398409426940

[16] Zeitler, M.H., Kirchgessner, M. and Schwarz, F.J. (1984) Effects of Different Protein and Energy Supplies on Carcass 
Composition of Carp (Cyprinus carpio L). Aquaculture, 36, 37-48. http://dx.doi.org/10.1016/0044-8486(84)90052-8

[17] D’Mello, J.P.F., Ed. (1994) Amino Acids in Farm Animal Nutrition. CAB International, Wallingford.

[18] Schwarz, F.J. and Kirchgessner, M. (1988) Amino Acid Composition of Carp (Cyprinus carpo L) with Varying Protein and Energy Supplies. Aquaculture, 72, 307-317. http://dx.doi.org/10.1016/0044-8486(88)90219-0

[19] Wunsche, J. and Steffens, W. (1968) Der Gehalt an essentiellen Aminosauren im protein von parpfen (Cyprinus carpio). Regeabogenforelle (Salmo gairdoeri). Kleiner Marane (Corgenus albule). Hecht Esor Lucius und Aal (Anguilla Anguilla). Z. Fisherei NF, 16, 301-304.

[20] Gaber, M.M., Zaki, M.A., Nour, A.M. and Salem, M.El.-S. (2015) Amino Acid Requirements of Sea Bass (Dicentrarchus labrax). International Journal of Agriculture Science and Natural Resources, 2, 40-45.

[21] Gaber, M.M. (1994) Amino Acid Requirements and Body Composition of Tilapia Mossambicus. Annals of Agriculture Science of Moshtohor, 33, 1225-1236.

[22] Njaa L.R. and Utne, F. (1982). A Comparison of the Amino Acid Compositions of Fifteen Species of Whole Fish. Fisk. Skr., Ernearing, 2, 25-33.

[23] Gunasekera, R.M., Shim, K.F. and Lam, T.J. (1997) Influence of Dietary Protein Content on the Distribution of Amino Acids in Oocytes, Serum and Muscle of Nile Tilapia (Oreochromis niloticus). Aquaculture, 152, 205-221. http://dx.doi.org/10.1016/S0044-8486(96)01526-8

[24] Gatlin, D.M. (1987) Whole Body Amino Acid Composition and Comparative Aspects of Amino Acid Nutrition of Goldfish, Golden Shiner and Flathead Minnow. Aquaculture, 60, 223-229. http://dx.doi.org/10.1016/0044-8486(87)90289-4

[25] El-Saidy, D.M. and Gaber, M.M. (1998) Amino Acid Requirements and Body Composition of Nile Tilapia (Oreochromis niloticus). Annals of Agriculture Science of Moshtohor, 36, 163-174.

[26] Steinhart, H. (1983) Moglich keiten der Aufwertun von Elwessfutter mitteln in der schweinemast. Kraftfutter, 66, 314-318.

[27] Lovell, R.T. (1989) Nutrition and Feeding of Fish. Van Nostrand Reinhold, New York. http://dx.doi.org/10.1007/978-1-4757-1174-5

[28] Jauncey, K., Tacon, A.C.J. and Jackson, A.J. (1983) The Quantitative Essential Amino Acid Requirements of Oreochromis (Sarotherodon) Mossambicus. In: Fishelson, J. and Yaron, Z., Eds., Proc. 1st Intl. Symp. on Tilapia in Aquaculture, Tel Aviv University, Tel Aviv, 328-337.

[29] Wilson, R.P. and Halver, J.E. (1968) Protein and Amino Acid Requirements of Fishes. AnnU. Rev. Nutr, 6, $225-244$. http://dx.doi.org/10.1146/annurev.nu.06.070186.001301

[30] Zeitler, M.H., Schwarz, F.J. and Kirchgessner, M. (1983) Wachstum und Nabrstoffaufwand bei karpfen (Cyprinus carpio L) mit unterschiedlicher protein-und Energieversorgugn I. Mitteilung: Versuchsplan, Rationszusammensetzung. Nahrstoffreedaulichkei Z. Tierphysiol Tierernahr Futtermittelkd, 49, 86-87.

[31] Tibaldi, E., Tulli, F. and Corsin, F. (1996) Current Estimates of the Essential Amino Acid Requirements of Sea Bass (D. labrax) as Determined by Unconventional Methods. In: Chatain, B., Saroglia, M., Sweetman, J. and Lavens, P., Eds., Proceedings of the International Workshop on Seabass and Seabream Culture: Problems and Prospects, Verona, European Aquaculture Society, Oostende, 320-323.

[32] Boorman, K.N. (1980) Dietary Constraints on Nitrogen Retention. In: Batter, P.J. and Lindsey, D.B., Eds., Protein Deposition in Animals, Butterworths, London, 147-166. http://dx.doi.org/10.1016/b978-0-408-10676-4.50013-6

[33] Thebault, H., Alliot, E. and Pastoureaud, A. (1985) Quantitative Methionine Requirement of Juvenile Sea-Bass (Dicentrarchus labrax). Aquaculture, 50, 75-87. http://dx.doi.org/10.1016/0044-8486(85)90154-1 


\section{Submit or recommend next manuscript to SCIRP and we will provide best service for you:}

Accepting pre-submission inquiries through Email, Facebook, LinkedIn, Twitter, etc.

A wide selection of journals (inclusive of 9 subjects, more than 200 journals)

Providing 24-hour high-quality service

User-friendly online submission system

Fair and swift peer-review system

Efficient typesetting and proofreading procedure

Display of the result of downloads and visits, as well as the number of cited articles

Maximum dissemination of your research work

Submit your manuscript at: http://papersubmission.scirp.org/ 